DOI: 10.2478/atd-2022-0009

\title{
EFL Teachers' Sources of Remote Teaching Anxiety: Insights and Implications for EFL Teacher Education
}

\author{
Yunus Emre Akbana - Kenan Dikilitaş* \\ Received: August 11, 2021; received in revised form: October 11, 2021; \\ accepted: October 12, 2021
}

\begin{abstract}
:
Introduction: This study aims to explore an under-researched issue; namely, remote teaching anxiety.

Methods: This study employed a sequential mixed-methods exploratory design where participants initially reported their remote teaching anxiety sources and then rated each. For the analysis, inductive content analysis and statistical tests were employed.

Results: The content analysis revealed two major themes: digitalisationrelated concerns and online pedagogy-related concerns. Statistically significant difference was only found between anxiety sources and online teaching experience but not between gender, age, teaching experience, work setting and anxiety sources.

Discussion: Several studies (Çoklar, Efilti, Şahin, \& Akçay, 2016; Hassan et al., 2019) found digitalisation-related concerns causing stress among teachers; however, remote teaching anxiety remains an underexplored construct (Russell, 2020). Although online pedagogy-related concerns were found to cause teaching anxiety in our study, a recent study (Lazarevic \& Bentz, 2020) found using technology helpful to decrease anxiety.
\end{abstract}

Limitations: The data were limited to the views of 96 EFL teachers in the Turkish context.

Conclusion: We can conclude that limited experience with remote teaching can contribute to higher anxiety among EFL teachers. Additionally, this research can contribute to the relevant literature with several implications on the future of language education.

Key words: anxiety, Covid-19, English as a foreign language, remote teaching anxiety, sources of anxiety.

\footnotetext{
* Yunus Emre Akbana, Kahramanmaras Sutcu Imam University, Faculty of Education, Kahramanmaras, Turkey; yunusemreakbana@gmail.com

Kenan Dikilitaş, University of Stavanger, Faculty of Arts and Education, Stavanger, Norway; kenandikilitas@gmail.com
} 


\section{Acta Educationis Generalis \\ Volume 12, 2022, Issue 1}

\section{Introduction}

As a result of the abrupt and extraordinary circumstances stemming from the novel Covid-19 pandemic, a serious impact was observed in the field of education (Liguori \& Winkler, 2020). Schools and universities across the world were closed (UNESCO, 2020). This revealed and reaffirmed a longstanding potential challenge to education (Crawford, Butler-Henderson, Rudolph, \& Glowatz, 2020). However, it seems that the new aspects of online teaching and learning have not yet been understood adequately, which created a norm rather than an exception in the form of emergency remote teaching (ERT). An area of research emerged for educational researchers: the exploration of the initial experiences related to ERT. We therefore focus our research on English as a foreign language (EFL) teachers' online teaching experiences related to teaching anxiety, which has been observed by the first author since the onset of the Covid-19 outbreak leading to a massive growth in online teaching in Turkey and the world.

Schools, as well as individual teachers, had to move courses online, which shifted the concept of learning to home-schooling behind computer screens, also qualified as 'online' or 'remote' teaching (Crawford et al., 2020). The two terms are used interchangeably within the scope of this study, meaning the new modality of ERT in concern. ERT was sustained without the physical presence of others in an unprecedented way globally. A small number of pedagogical studies introduced the transition in the related literature; in Turkey by Özer (2020), India by Lall and Singh (2020), Georgia by Basilaia and Kvavadze (2020), and across 20 countries by Crawford et al. (2020). As a very recent phenomenon, this abrupt and previously unplanned shift to massive online teaching has yet to be explored, particularly with more attention into EFL teachers' anxiety about such an emergency shift (Bollinger, 2017; Russell, 2020). In this context, we aim to reveal the potential sources of anxiety triggered by online teaching experiences of EFL teachers and to understand the degree to which the teachers were affected by each source. We draw on a set of qualitative data collected from 96 Turkish EFL teachers through an open-ended questionnaire that includes a broad question and a quantifying 10-likert scale. We addressed the following research questions:

1. What are the sources of online teaching anxiety reported by EFL teachers?

2. To what extent do they score these sources influencing their online teaching anxiety?

3. Do these scores show any statistically significant difference in terms of demographic variables? 


\section{Acta Educationis Generalis \\ Volume 12, 2022, Issue 1}

\section{Literature review}

A wide range of digital technologies enables us to design and implement online teaching by generating a widespread impact on learning and teaching (Rodrigues, Almeida, Figueiredo, \& Lopes, 2019). However, there are relatively few studies investigating online teaching anxiety as perceived by teachers (Russell, 2020), which is a gap this study addresses. Below we portray the construct of anxiety as well as affordances and constraints in online EFL teaching.

\subsection{Challenges and opportunities in online teaching and learning}

Teaching a foreign language by embedding Information and Communication Technologies is not a new phenomenon (Ellis \& Calvo, 2007); however, it certainly remains challenging in many terms. The often-cited challenges in online education include the need for teachers to ensure satisfaction among learners (Picciano, Seaman, Shea, \& Swan, 2012), embedding the required teaching tools to decrease students' anxiety in online learning (Russell, 2020), and employing accurate assessment and evaluation methods (Sahu, 2020). However, these challenges could stem from anxiety during ERT since neither learners nor teachers know how to overcome the challenges derived from the rapidly shifted modality of education. Hubalovsky, Hubalovska and Musilek (2019) argue that teachers' anxiety in online platforms stems from the need to deal with a variety of approaches, applications, processes and academic areas. Online education may require language teachers to be autonomous, creative, digitally literate, evaluative and good at monitoring the whole learning process and language teachers also need to know how to situate learning authentically in their own classroom (Driscoll, Jicha, Hunt, Tichavsky, \& Thompson, 2012). It is also important to ensure continuous opportunities for interaction and information exchange (Ross \& DiSalvo, 2020) as well as socio-emotional information and the autonomy to exercise choices (Paechter, Maier, \& Macher, 2010). Accomplishing these roles in the new modality of teaching might cause stress and anxiety among EFL teachers.

While online education helps teachers become creative and unique, learners also start to become more critical and engaged in learning through technologyassisted learning (Young, 2003). Students' learning performance can be correlated with their anxiety levels and other technological competences. In a recent technology-assisted study, Yang, Lin, and Chen (2018) found that students with high-levels of anxiety performed worse in learning a foreign language than those with low-level anxiety. Language teachers could also consider such a debilitative effect of anxiety on their teaching performance mutually. Therefore, teachers should feel the need to be equipped for teaching online at satisfactory levels (Picciano et al., 2012). They also need to meet the objectives of the course, content, interaction and students' learning needs with the appropriate pedagogy (Driscoll et al., 2012). 


\section{Acta Educationis Generalis \\ Volume 12, 2022, Issue 1}

During the ERT period, several studies have looked at the challenges of online education through language teachers' lenses and presented solutions. For example, Moorhouse and Beaumont (2020) suggested a 3-stage lesson sequence model starting with an offline pre-live lesson talk, followed by a live-video conferencing lesson, and ending with a post-live lesson talk over a learning management system. Kohnke and Moorhouse (2020) promoted an online synchronous meeting tool (Zoom) for augmenting interaction and letting introverted students to express themselves better. Taguchi (2020) argued teaching the pragmatics of digitalisation through structured (e.g. instructor designed games), semi-structured (computer learning partner), and unstructured (games or social networking sites) digital spaces. In addition, in their study mirroring the lessons learned at a language centre at Harvard University, Ross and DiSalvo (2020) suggested employing professional online communities for reflection on professional practice. On the other hand, Russell (2020) proposed that anxiety was felt by both teachers and learners during ERT and attempted to bring some research-based pedagogical techniques for teachers to help their students. The teachers as the sources of knowledge need to be researched first since they experienced anxiety as well. For this reason, the current study is one of the first to investigate an underlying phenomenon of the core of challenges (i.e. sources of online teaching anxiety) felt by EFL teachers during the transition from face-to-face education to online/remote education.

\subsection{Anxiety in online EFL teaching}

Temporary school closures could create both confusion and stress for learners as well as for teachers, since it can be highly challenging and frustrating to sustain support for learning on digital platforms (UNESCO, 2020). Such circumstances require further research-based evidence to generate knowledge that informs educational practices. We now discuss the previous literature drawing on anxiety as one of the key constructs in EFL teaching.

There are a wide range of sources of anxiety stemming from human and computer interactions in the educational field (Fernández-Batanero, RománGraván, Reyes-Rebollo, \& Montenegro-Rueda, 2021). In face-to-face education, Young (1991) identified personal reasons, learners and teachers' beliefs and their mutual interactions, classroom requirements, and assessment and evaluation causing anxiety. Due to the educational restrictions caused by the outbreak of Covid-19, learners and teachers have shown psychological reactions to their loneliness, resilience and resistance to the change through anxiety. Language teachers experienced anxiety due to the abrupt shift to online teaching. Recently, MacIntyre, Gregersen and Mercer (2020) have found that language teachers developed avoidant coping strategies, which correlated with stress, anxiety, anger, sadness, and loneliness. Although these negative outcomes stem directly from Covid-19, sources of such emotions need to be tackled. For example, anxiety in online EFL classrooms has not received sufficient attention 


\section{Acta Educationis Generalis \\ Volume 12, 2022, Issue 1}

from researchers. With specific reference to Iranian EFL teachers' teaching anxiety, Aslrasouli and Vahid (2014, p. 304) found five categories of sources of anxiety: interpersonal relations, language proficiency and knowledge, facilities and resources, employment structure, and other factors. These sources in face-toface modality show similarity to those evidenced in Turkey. For example, İpek (2016, p. 100) revealed five sources of anxiety of tertiary-level Turkish EFL instructors: "making a mistake, teaching a particular language skill, using the native language, teaching students at a particular language proficiency level and fear of failure. However, the anxiety construct might show a difference in the new modality on which research lacks empirical evidence. More recently, Russell (2020) has reported pedagogical techniques to deal with foreign language anxiety during ERT, but the report lacks evidence of EFL teachers' personal views. Similarly, other recent studies present only recommendations for language teachers to survive professionally in online education (e.g. Kohnke \& Moorhouse, 2020; Moorhouse \& Beaumont, 2020; Russell \& DiSalvo, 2020, Taguchi, 2020). On the other hand, in their systematic review of 16 studies which were published before the outbreak of Covid-19, Fernández-Batanero et al. (2021) report that teachers feel stressful and anxious about using technology as an innovation due partly to lack of technology knowledge, technology insecurity, high levels of techno-stress and pressure to use technology. Compared to the dearth of studies investigating online teaching anxiety after Covid-19, the current study attempts to explore and explain the sources of online teaching anxiety among EFL teachers.

\section{Methodology}

\subsection{Research design}

Since the uniqueness of the circumstances suggests previously unexplored themes in online teaching anxiety, we decided to take a bottom-up approach. To do so, we adopted an exploratory inductive approach to capturing and collecting the online teachers' initial feelings of anxiety through a qualitative research perspective (Dikilitaş, 2015). Secondly, we employed a quantitative research method by asking the participants to rate their self-identified anxiety sources. For this purpose, we chose a sequential mixed-methods exploratory design for two reasons: (I) we did not know the instruments, variables and measures available for a population (Creswell, 2011) and (II) remote teaching was an emerging field of research during the implementation of this study. Therefore, we explored the phenomenon of anxiety in online teaching, collected qualitative data and finally explained it through quantitative data (Creswell, 2011, p. 543). Our study is unique and grounded in that it quantifies the qualitative data and correlates it with the self-reported anxiety scores. The implementation matrix in Figure 1 shows the phases, procedures, products, and each rationale. 


\section{Acta Educationis Generalis \\ Volume 12, 2022, Issue 1}

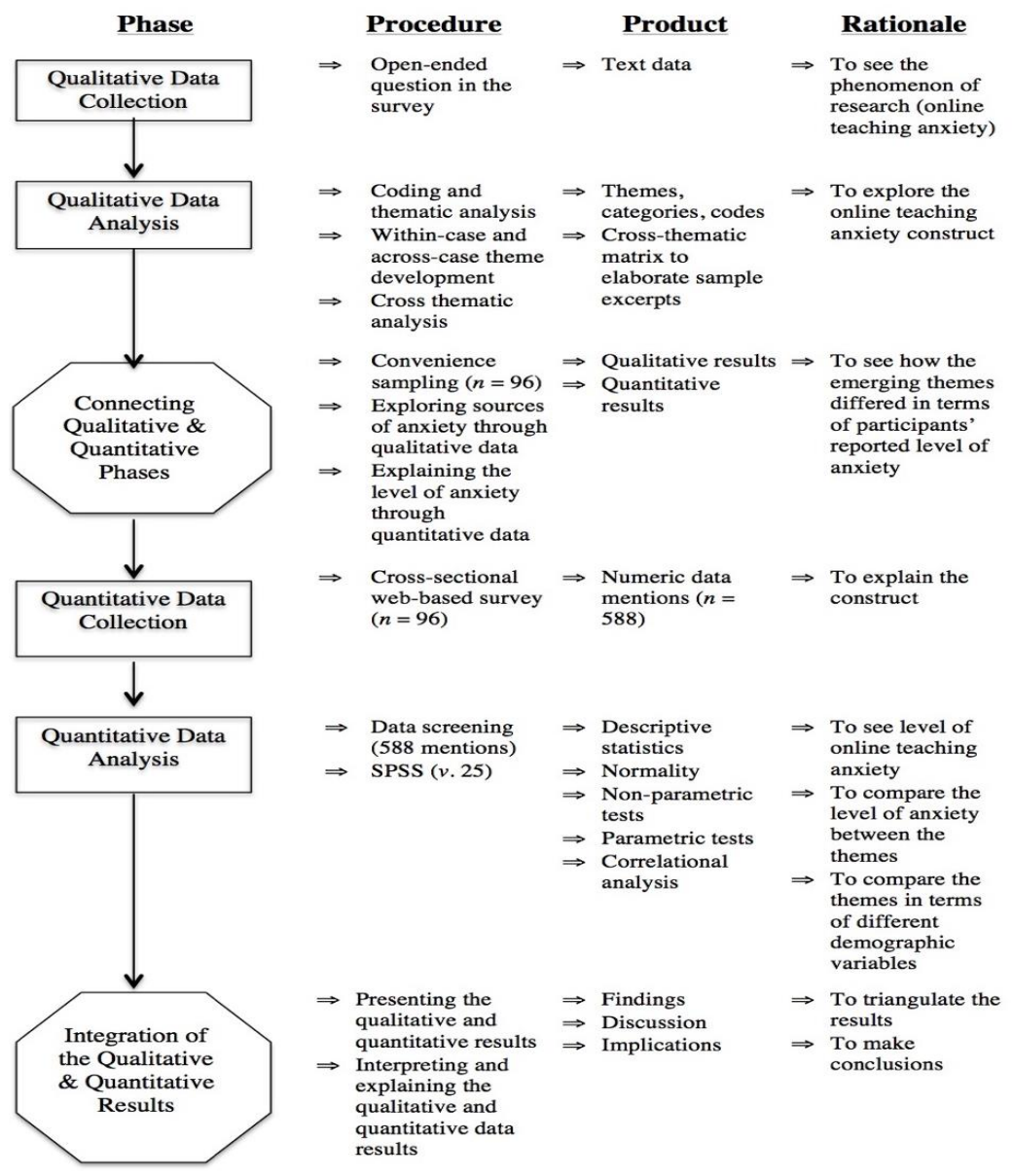

Figure 1. Implementation matrix of the design procedures.

In the sequential model, we employed open-ended questions to reveal previously unexplored themes and used close-ended questions to allow the participants to rate each anxiety source they reported. Therefore, one open-ended question and a rating closed-ended question followed each other in a sequence providing the base for the design of this study. The first research question was addressed through a qualitative research method, which explored EFL teachers' initial feelings, while the second helped us explain the level of each anxiety source through correlational statistics. Finally, the third research question investigated if the sources differed across demographic variables to triangulate the results and reveal deeper understanding of the phenomena. 


\section{Acta Educationis Generalis \\ Volume 12, 2022, Issue 1}

\subsection{Participants}

The study included convenience sampling by relying on the principles of accessibility to and willingness of participants (Creswell, 2011). We prepared an online survey and shared it with 234 EFL teachers in Turkey, 96 of whom responded. This is considered highly satisfactory number in qualitative terms (Dörnyei, 2007). The teachers' average age ranged from 23 to $62(\mathrm{M}=35.79$; $\mathrm{SD}=7.27)$. Sixty-seven were female $(69.8 \%)$ and 29 were male (30.2\%). Fortytwo of them were teaching at a university while 51 at K-12 level and only three at language centre. Their average year of teaching experience was 12.46 $(\mathrm{SD}=7.35)$ whereas that of online teaching was $1.19(\mathrm{SD}=2.15)$, which we categorized as none $(n=28)$, low $(n=38)$ and high $(n=30)$ corresponding to $<1$ day, $<20$ days and $>21$ days, respectively, as Table 1 displays:

Table 1

Participants' experience in online teaching

\begin{tabular}{lcc}
\hline Degree of experience & $\underline{F}$ & $\underline{\%}$ \\
None $(<1$ day $)$ & 28 & 29.16 \\
Low $(<20$ days $)$ & 38 & 39.58 \\
High $(>21$ days $)$ & 30 & 31.25 \\
\hline
\end{tabular}

\subsection{Data collection tools}

We used an online survey on Google Forms between March 31st and April 9th 2020 , to elicit teachers' sources of online teaching anxiety in the initial period of the transition to ERT in Turkey. We piloted it with five different EFL teachers and found that the survey was understood well by the participants; so we did not make any amendments and shared the survey link. We conducted the survey in Turkish to allow the participants to express their thoughts freely. In the survey, we clearly informed the participants that they take the survey with their own consent and that their anonymity would be ensured. The survey also elicited demographic information on participants' age, gender, teaching face-to-face and online experience in addition to the number of students they teach. We primarily asked the participants to share up to 10 sources of online teaching anxiety and rate the degree of each source of anxiety from 1 (very low) to 10 (very high). Their qualitative responses and quantitative ratings helped us answer the first and the second research question, respectively. This is the unique feature of this grounded research in that the participants self-identified their sources of anxiety and then self-scored each.

\subsection{Data analysis}

We first counted the participants' sources of online teaching anxiety and found 588 mentions. Following that, we ran an inductive analysis by coding the data, 


\section{Acta Educationis Generalis \\ Volume 12, 2022, Issue 1}

first independently and then engaged in a simultaneous re-negotiation to establish the sub-themes to reveal the categorical information emerging from our data (Miles \& Huberman, 1994; Saldaña, 2021). We iteratively coded the themes until we established a comprehensive and interconnected set of themes (Creswell, 2007). Finally, we elicited two themes with seven categories out of a total of 51 codes for the sources of online teaching anxiety. There were a number of novel categories, which may be connected with the study's specific context regarding anxiety phenomena (e.g., abrupt transition, generating online learning environments, perceiving low student interest).

As for the quantitative data, we quantified the qualitative data in order to triangulate the results. The quantified data were exposed to SPSS (v. 25) to run descriptive tests through the number and scoring of the mentions for eliciting mean and standard deviations. The data were then triangulated by comparing each theme with a set of demographic variables such as the participants' gender, age, work setting, overall teaching experience and digital teaching experience. For the triangulation, initially the normality of the dataset was calculated through tests suggested by Tabachnick and Fidell (2007): Kolmogorov Smirnov Test (p $>0.05)$, Skewness $( \pm 1)$, Kurtosis $( \pm 1)$, Skewness/SE $(<1.96)$, Kurtosis/SE $(<1.96)$.

To be able to compare the implicated results by considering demographic variables, we calculated the normality of the dataset initially and then for each theme separately. Finally, we decided on the individual test types. Non-normal distribution was found for the whole dataset, therefore Wilcoxon Signed Test was used to see significant differences and Spearman's rho test to see correlation between the two themes. Non-parametric tests were used for 'Online pedagogyrelated concerns' while parametric tests were used for 'Digitalisation-related concerns' due to the separate normality test results.

\subsubsection{Triangulation of the data}

Triangulation of the data has been ensured through the qualitative data from the open-ended question and the quantitative data from the participants' scoring of their responses. To triangulate the findings, firstly, the qualitative data were quantified by hand counting participants' mentions, which provided the number of each source of anxiety. Secondly, as the participants rated each source of anxiety, this provided the anxiety level for each corresponding mention. The demographic information of the participants was used as a variable for comparisons between the themes. Finally, the answers to each research question were triangulated in the findings.

\subsection{Credibility and trustworthiness}

The present study is drawn mostly on the qualitative data; therefore, it must be validated through scientific credibility (Creswell, 2007). It should be achieved as meticulously as in quantitative studies through concepts such as validity and 


\section{Acta Educationis Generalis \\ Volume 12, 2022, Issue 1}

reliability (Creswell \& Poth, 2016). An understanding of credibility of the data was established through informing the participants on the purpose of the study, asking participants' consent, and allowing them to withdraw at any phase of the survey; and in the findings, ensuring their anonymity in their quoted sample excerpts. We also employed debriefing technique (McMahon \& Winch, 2018), firstly between researchers, and then with two outsiders experienced in qualitative analysis (Creswell, 2011; Guba \& Lincoln, 2005): a researcher with $\mathrm{Ph} . \mathrm{D}$. in ELT and a professor of digitalisation in education. We provided a thick description on the research process in order to increase transferability of the findings to other similar contexts (Guba \& Lincoln, 1989). The findings show that the data is objective as the phenomenon - online teaching anxiety - is evidenced through the participants' self-prompted concerns and self-rated constructs and could further be confirmed by comparing the labels emerging from the categories and the sample excerpts.

\section{Findings}

To address research question 1 regarding the sources of online teaching anxiety, we employed an exploratory approach in the initial stage. We identified sources of online teaching anxiety under two broad themes, digitalisation-related concerns and online pedagogy related concerns. The theme of digitalisation involves cognitive and affective aspects of information in terms of integration, availability and confidentiality (Tekerek \& Tekerek, 2013) while online pedagogy covers the act of teaching senses in digital classrooms. The codes and categories show that participants touched upon their sources of anxiety related to their digital literacy and digital pedagogy concerns as they faced an unplanned transformational education abruptly. Figure 2 shows the quantified dominance.

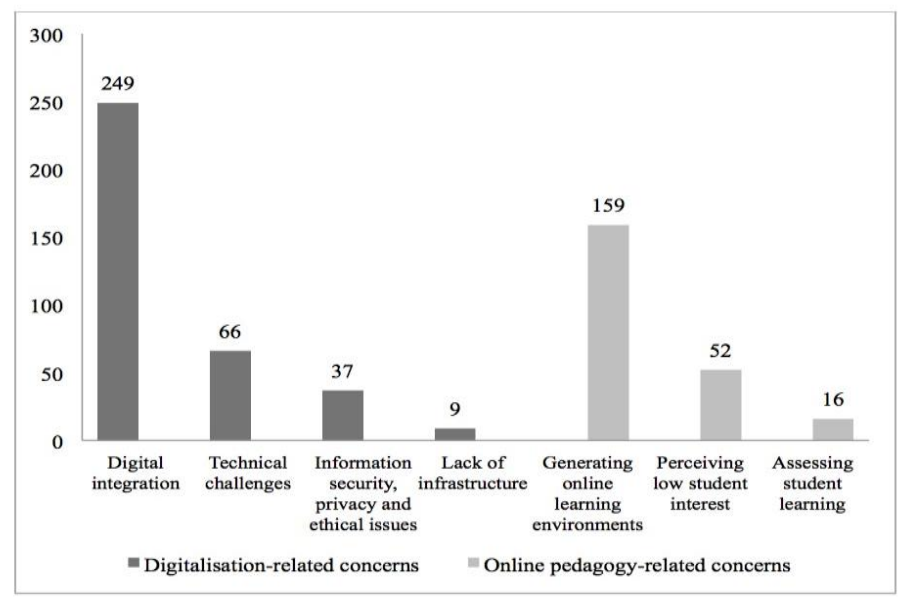

Figure 2. Categories induced under each theme. 


\section{Acta Educationis Generalis \\ Volume 12, 2022, Issue 1}

Figure 2 shows the distribution of 588 mentions across the categories under the two main themes. The sources of anxiety show a dispersing distribution from high to low common concerns where digitalisation-related concerns $(\mathrm{n}=361)$ outweigh those of online pedagogy-related concerns $(n=227)$. Table 2 shows the results of the inductive analysis with sample excerpts on digitalisationrelated concerns below.

\section{Table 2}

Digitalisation-related concerns and sub-categories

\begin{tabular}{|c|c|c|}
\hline Category & Code & Sample Excerpt \\
\hline \multirow[t]{3}{*}{$\begin{array}{l}\text { Technical } \\
\text { Challenges }\end{array}$} & Hardware & $\begin{array}{l}\text { "Again, technical problem related, speakers may not } \\
\text { work properly so the students cannot hear the teacher } \\
\text { or each other." (P96) }\end{array}$ \\
\hline & Software & $\begin{array}{l}\text { "There are some technical problems arisen from using } \\
\text { the LMS of the university. I cannot deal with them." } \\
\text { (P14) }\end{array}$ \\
\hline & Students'facilities & $\begin{array}{l}\text { "Some of my students may not have properly working } \\
\text { devices or Internet connection that I cannot be of any } \\
\text { help." (P28) }\end{array}$ \\
\hline Lack of & Hardware & "I don't have the required devices." (P84) \\
\hline Infrastructure & Software & $\begin{array}{l}\text { "I don't have software programs to teach English." } \\
\text { (P56) }\end{array}$ \\
\hline \multirow[t]{9}{*}{$\begin{array}{l}\text { Digital } \\
\text { Integration }\end{array}$} & Assignment & $\begin{array}{l}\text { "Having students do and check their homework after } \\
\text { the online class." (P6) }\end{array}$ \\
\hline & Being a multitasker & $\begin{array}{l}\text { "Well, I have to manage my classes online even } \\
\text { outside of the lesson time. I have to help them } \\
\text { navigate the platform or add my students to the class } \\
\text { myself. It's all time consuming." (P96) }\end{array}$ \\
\hline & Communication & $\begin{array}{l}\text { "Students ask me to check my e-mail box if they had } \\
\text { uploaded their homework properly." (P83) }\end{array}$ \\
\hline & Lack of knowledge & $\begin{array}{l}\text { "I don't have the specific knowledge of Web } 2.0 \text { tools, } \\
\text { so I can't produce relevant activities." (P70) }\end{array}$ \\
\hline & $\begin{array}{l}\text { Management of } \\
\text { materials }\end{array}$ & $\begin{array}{l}\text { "I find it difficult to create authentic materials for } \\
\text { online courses." (P11) }\end{array}$ \\
\hline & Prepararation & "I will have to do more lesson preparation." (P27) \\
\hline & $\begin{array}{l}\text { Professional } \\
\text { support }\end{array}$ & $\begin{array}{l}\text { "The institute did not give us any training or specify } \\
\text { the resources we could use. There are many resources } \\
\text { on the Internet and preparing lessons can sometimes } \\
\text { take a long time. I think it would be better if they } \\
\text { helped with this."(P34) }\end{array}$ \\
\hline & $\begin{array}{l}\text { Students' lack of } \\
\text { knowledge }\end{array}$ & $\begin{array}{l}\text { "My students don't have command over using } \\
\text { technology." (P63) }\end{array}$ \\
\hline & Transferability & $\begin{array}{l}\text { "Transferring the courses planned for face to face } \\
\text { teaching into a digital environment costs challenges." } \\
\text { (P30) }\end{array}$ \\
\hline
\end{tabular}




\begin{tabular}{|c|c|c|}
\hline \multirow[t]{14}{*}{ Category } & Code & Sample Excerpt \\
\hline & Unpreparedness & $\begin{array}{l}\text { "There are no pre-determined outputs for the } \\
\text { curriculum compatible with the digital teaching." } \\
\text { (P34) }\end{array}$ \\
\hline & Use of modality & $\begin{array}{l}\text { "I am not able to use the digital platform which makes } \\
\text { me feel doing one-man show." (P43) }\end{array}$ \\
\hline & Abruptness & $\begin{array}{l}\text { "The abrupt transition to digital teaching makes me } \\
\text { feel nervous." (P30) }\end{array}$ \\
\hline & Authenticity & $\begin{array}{l}\text { "The level of emotional contact is low and it makes } \\
\text { the things unnatural." (P73) }\end{array}$ \\
\hline & Cyberharrassment & "Fear of students' sabotaging the lesson." (P13) \\
\hline & Implausibility & $\begin{array}{l}\text { "I don't know how effective/efficient this process is } \\
\text { for students. But I try to support as much as I can." } \\
\text { (P83) }\end{array}$ \\
\hline & Isolation & "I think I am getting isolated from my students. (P34) \\
\hline & Surveillance & $\begin{array}{l}\text { "Sense of being watched triggers my camera phobia." } \\
\text { (P51) }\end{array}$ \\
\hline & $\begin{array}{l}\text { Self- } \\
\text { esteemlessness }\end{array}$ & $\begin{array}{l}\text { "I don’t feel secure since teacher quality is under } \\
\text { question." (P70) }\end{array}$ \\
\hline & Self-image & $\begin{array}{l}\text { "I have hesitations about my appearance since I may } \\
\text { not be photogenic enough." (P24) }\end{array}$ \\
\hline & Tension & $\begin{array}{l}\text { "Dissatisfaction due to the fact that I cannot run my } \\
\text { teaching as I wish." (P45) }\end{array}$ \\
\hline & Tiredness & $\begin{array}{l}\text { "Even though the time for each class hour in online } \\
\text { teaching is low, it makes me more tired." (P38) }\end{array}$ \\
\hline & Trajectory & $\begin{array}{l}\text { "Having the teacher, who has already taught for } 20 \\
\text { years in f2f format forced into digital learning } \\
\text { suddenly puts the teacher in difficulty". (P87) }\end{array}$ \\
\hline \multirow{3}{*}{$\begin{array}{l}\text { Information } \\
\text { Security, } \\
\text { Privacy and } \\
\text { Ethical Issues }\end{array}$} & Confidentiality & $\begin{array}{l}\text { "The existence of students' parents makes me feel that } \\
\text { I am under their control." (P72) }\end{array}$ \\
\hline & Copyright & $\begin{array}{l}\text { "There may be some problems related to the copyright } \\
\text { issues of the materials we use in online teaching." } \\
\text { (P11) }\end{array}$ \\
\hline & Fear of hack & $\begin{array}{l}\text { "My personal data can easily be transferred from my } \\
\text { device in the virtual environments." (P94) }\end{array}$ \\
\hline
\end{tabular}

Table 2 lists the categories related to the teachers' sources of online teaching anxiety based on digitalisation, a very dominant theme closely related to their technical concerns and digital literacy skills. To illustrate, teachers have doubts which can occur beyond their control, for example possible failures stemming from issues with the Internet connection and via their delivery of communication tools such as computer devices (i.e. speakers), and similar concerns about students' own facilities. As P59 noted "the fact that some students do not have the opportunity to access to the Internet or technnological devices makes me feel anxious", there may occur problems that teachers cannot solve but cause them to be anxious about their students' learning due to external factors that they cannot 


\section{Acta Educationis Generalis \\ Volume 12, 2022, Issue 1}

cover. Another issue is to do with the lack of infrastructure in terms of both hardware and software. The very dominant category was found with the teachers' lack of ability to integrate their teaching endeavours into the digital medium, according to their cognitive and affective perspectives. Their affective concerns ranged from the codes' abruptness to trajectioral change, and their conceptualization of their own teaching selves led to various fears that constituted their sources of online teaching anxiety. Digging in this dominant category, ample findings are revealed on digital integration-related sources of anxiety: Firstly, they need professional support from their institutions, a pre-set curriculum aligning with digital teaching requirements, the ability to select and create digitally authentic materials and to embed specific knowledge of Web 2.0 tools into remote teaching. For example, P56's statement is well-sounded evidence on that issue: "I haven't been educated to teach via digtial platforms." Secondly, they report hesitations on how to integrate themselves digitally due to their dissatisfaction, low level of emotional contact, weariness, feeling of isolation and inability to control student behaviours. Finally, some teachers seem to show resistance to change by reporting on the forced efforts to be a multitasker, due to their lack of digital teaching experience, and they do not seem to believe in the power of teaching online, where their physical existence should be felt. For instance, as illustrated by P87 who noted that "as a teacher with over 20 years of teaching experience, I am not satisfied with my teaching where I see myself as another person who deals with other things on a computer", some teachers showed resistance to the change caused by the pandemic. The last category signals that mutual trust and consent are sought among the teachers in the digital environment, because the teachers express feeling insecure about the third parties' access to their own personal data, and their online classroom confidentiality, and finally, use of digital sources. Also, the emerging categories made up of the EFL teachers' online pedagogy-related concerns, of which the inductive analysis results are shown in Table 3 below.

Table 3

\begin{tabular}{|c|c|c|}
\hline \multirow{8}{*}{$\begin{array}{l}\text { Category } \\
\text { Generating } \\
\text { Online } \\
\text { Learning } \\
\text { Environments }\end{array}$} & Code & Sample Excerpt \\
\hline & $\overline{\text { Authority }}$ & "I can't build authority because the class hours \\
\hline & building & in $\mathrm{f} 2 \mathrm{f}$ teaching is 50 minutes, but this is 20 \\
\hline & & minutes in digital teaching." (P28) \\
\hline & & \\
\hline & Disciplining & $\begin{array}{l}\text { "I can't secure discipline because some online } \\
\text { classes are crowded." (P29) }\end{array}$ \\
\hline & $\begin{array}{l}\text { Boosting peer- } \\
\text { interaction }\end{array}$ & $\begin{array}{l}\text { "I can't organise the interaction among students as in } \\
\text { my real classroom." (P59) }\end{array}$ \\
\hline & Boosting & "The interaction is limited between the teacher and the \\
\hline
\end{tabular}




\section{Acta Educationis Generalis \\ Volume 12, 2022, Issue 1}

\begin{tabular}{|c|c|c|}
\hline \multirow[t]{9}{*}{ Category } & $\frac{\text { Code }}{\text { interaction }}$ & $\begin{array}{l}\text { Sample Excerpt } \\
\text { students in the course of I am teaching online." (P25) }\end{array}$ \\
\hline & $\begin{array}{l}\text { Patterning } \\
\text { interaction }\end{array}$ & $\begin{array}{l}\text { "The fact that I can't run pair or group activities in game } \\
\text { formats." (P28) }\end{array}$ \\
\hline & $\begin{array}{l}\text { Checking } \\
\text { comprehension }\end{array}$ & $\begin{array}{l}\text { "I don't feel sure whether all the students can } \\
\text { understand the material or the subject matters } \\
\text { sufficiently." (P38) }\end{array}$ \\
\hline & Feeling biased & $\begin{array}{l}\text { "Staying in the dilemma about the way of teaching } \\
\text { makes it hard to decide how to teach." (P38) }\end{array}$ \\
\hline & $\begin{array}{l}\text { Giving and } \\
\text { receiving } \\
\text { feedback }\end{array}$ & $\begin{array}{l}\text { "I can't give and receive sufficient immediate } \\
\text { feedback." (P88) }\end{array}$ \\
\hline & $\begin{array}{l}\text { Instructional } \\
\text { talking }\end{array}$ & $\begin{array}{l}\text { "Not being understood creates anxiety of inability to } \\
\text { express myself."(P32) }\end{array}$ \\
\hline & Lecturing & $\begin{array}{l}\text { "I often run teaching alone and the course turns into a } \\
\text { monologue." (P78) }\end{array}$ \\
\hline & Managing time & $\begin{array}{l}\text { "It must be very difficult to cope with time management } \\
\text { in online teaching." (P6) }\end{array}$ \\
\hline & Motivating & $\begin{array}{l}\text { "I don't feel that I am able to energise my students and } \\
\text { create enthusiasm." (P47) }\end{array}$ \\
\hline \multirow{5}{*}{$\begin{array}{l}\text { Perceiving } \\
\text { Low student } \\
\text { interest }\end{array}$} & $\begin{array}{l}\text { Access to } \\
\text { students }\end{array}$ & $\begin{array}{l}\text { "I find it difficult to reach students and this stresses me } \\
\text { professionally." (P9) }\end{array}$ \\
\hline & $\begin{array}{l}\text { Active } \\
\text { participation }\end{array}$ & "Students do not attend online classes constantly." (P85) \\
\hline & Commitment & "There is lack of seriousness in online learning." (P92) \\
\hline & Demotivation & “Students' lack of motivation demotivates me.” (P95) \\
\hline & Disengagement & “Students' unwillingness makes me feel upset.” (P29) \\
\hline \multirow[t]{4}{*}{$\begin{array}{l}\text { Assessing } \\
\text { Student } \\
\text { Learning }\end{array}$} & $\begin{array}{l}\text { Lack of } \\
\text { knowledge }\end{array}$ & $\begin{array}{l}\text { "I am uncertain about the examination system because I } \\
\text { don't have an idea about which assessment and } \\
\text { evaluation tools will be used." (P56) }\end{array}$ \\
\hline & Reliability & $\begin{array}{l}\text { "The idea that students get help from many people and } \\
\text { use resources during assessment and evaluation." (P25) }\end{array}$ \\
\hline & Usefulness & $\begin{array}{l}\text { "A teacher has no understanding about whether all the } \\
\text { students understood the material or not unless he } \\
\text { conducts some evaluation test." (P38) }\end{array}$ \\
\hline & Validity & $\begin{array}{l}\text { "Not being able to effectively assess and evaluate the } \\
\text { understanding of the subjects I teach is a source of } \\
\text { anxiety for me." (P38) }\end{array}$ \\
\hline
\end{tabular}

Table 3 displays three categories classified under the theme on online pedagogical concerns. The predominant category is creating an online learning environment. The teachers emphasised that they may not be able to secure the 


\section{Acta Educationis Generalis \\ Volume 12, 2022, Issue 1}

discipline and exert full control in the online classroom, a major issue also reported as to face-to-face teaching. It also seems that classroom management becomes more challenging in online teaching due partly to the inability to activate students through building interaction between their peers in pair or group activities and also with themselves. For example, as P25 expressed "the idea that I cannot let students interact with me and each other in pair-work and group-work activities authentically in online education triggers my anxiety", teachers see remote education lacking authenticity in terms of real-time interaction. In addition, the teachers are not sure whether students are actively involved in learning during online courses; their anxiety seems to stem from their inability to make students verbally active, to pass on relevant feedback, and develop a sense of teaching adequately. The second pedagogical concern is related to their perceptions of students' inadequate attempts and efforts to adapt to the online learning setting, which in turn seems to impact on the teachers' motivation, increasing nervousness and tension, as they cannot create sufficient student enthusiasm. In this regard it is paramount of significance to see P65's statement: "Students are not sufficiently active in online education though I do my best to get them involved but this causes me to feel in a way that I am and will not be able to create enthusiasm and energy required for a real teaching." because P65' statement reached in several codes such as generating online learning and students' lack of interest and this eventually shows EFL teachers' concern for being pedagogically equipped for teaching online. The last category is assessing student learning, in that teachers feel lack of experience to ensure fair testing and evaluation of student learning in online environments.

The research question 2 revealed the extent to which these sources influenced their online teaching anxiety. Table 4 compares this influence between the induced themes below.

Table 4

Wilcoxon signed ranks test results for comparing digitalisation and online pedagogical concerns

\begin{tabular}{lccccc}
\hline Themes & Positive Ranks & Negative Rank & $\underline{\text { Ties }}$ & $\underline{Z}$ & $\underline{p}$ \\
$\begin{array}{l}\text { Digitalisation- and Online } \\
\text { Pedagogy-Related Concerns }\end{array}$ & 51 & 43 & & -0.5 & 0.617 \\
\hline
\end{tabular}

Table 4 shows that no statistically significant difference was found between the two main themes although digitalisation-related concerns were mentioned more frequently than those related to online-pedagogy. Table 5 displays the degree of correlation. 


\section{Acta Educationis Generalis \\ Volume 12, 2022, Issue 1}

Table 5

Spearman's rho test results

\begin{tabular}{ccc} 
Themes & $r$ & $p$ \\
Digitalisation- and Online Pedagogy-Related Concerns & 0.024 & 0.814 \\
\hline
\end{tabular}

According to the correlation results shown in Table 5, no statistical significance difference and correlation was found between the two themes ( $\mathrm{r}=0.024$; $\mathrm{p}=0.814$ ). The most cited anxiety sources did not necessarily imply that these concerns led to anxiety among all participants in the same way. Therefore, these two themes do not have a causal relationship.

The collected data are jointly triangulated by presenting the number of mentions (f) as to each category and participants' scoring of each category from 1 (very low) to 10 (very high). Table 6 shows the triangulated results of the first theme.

Table 6

Descriptive test results of digitalisation-related concerns

\begin{tabular}{lcccc}
\multicolumn{1}{c}{$\quad$ Category } & \multicolumn{2}{c}{ Anxiety Mention } & & \multicolumn{1}{c}{ Anxiety Score } \\
Digital integration & 249 & & Mean & 2.07 \\
Technical challenges & 66 & 6.90 & 2.20 \\
Information security, privacy & 37 & 6.30 & 2.30 \\
and ethical issues & 9 & 7.77 & 2.09 \\
Lack of infrastructure & 361 & 7.18 & 2.14 \\
Total & &
\end{tabular}

The teachers produced a total number of 361 mentions in which they dominantly felt the need to get digitally integrated $(\mathrm{f}=249)$ with the most common ideas $(\mathrm{SD}=2.07)$ but scored it with the second highest degree $(\mathrm{M}=7.36)$ after their hesitations about the information security and their confidentiality $(M=7.77$; $\mathrm{SD}=2.09$ ). According to the qualitative findings on Table 2, the participants specifically noted their lack of ability to integrate their teaching endeavours into the digital medium according to their cognitive and affective perspectives. The conceptualisation of their own teaching revealed various fears that attract particular attention on their need for professional support from their institutions on how to be digitally integrated in terms of following a suitable curriculum and being able to digitally skilful, secure and safe. The category of 'Information security, privacy and ethical issues' shows this with a relatively low number of mentions ( $\mathrm{f}=37$ ) but as noted before with a high level of anxiety source $(\mathrm{M}=7.77 ; \mathrm{SD}=2.09)$. They also mentioned the technical challenges $(\mathrm{f}=66)$ with a relatively more concerns; however, they rated it with a mean score of 6.90 , not in the form of dispersed views $(\mathrm{SD}=2.20)$. Closely related to this category, nine 


\section{Acta Educationis Generalis \\ Volume 12, 2022, Issue 1}

concerns emerged about the 'lack of infrastructure' in both 'hardware' and 'software' related challenges with a mean score of $6.30(\mathrm{SD}=2.30)$. It was a concern linked to both low number of mentions and degree of anxiety.

Therefore, the participants' sources of anxiety are dominantly interrelated with their computer interactions, yet the results also shed light on pedagogical behaviours, which is a fairly new trend in covering teaching senses in ERT. Table 7 displays the descriptive results on the reported number and scoring of online pedagogy-related concerns.

Table 7

Descriptive test results of online pedagogy-related concerns

\begin{tabular}{lccl}
\hline Category & Anxiety Mention & $\underline{\text { Anxiety Score }}$ & \\
\cline { 2 - 3 } $\begin{array}{l}\text { Generating online } \\
\text { learning environments }\end{array}$ & $f$ & $\underline{\text { Mean }}$ & $\underline{S D}$ \\
$\begin{array}{l}\text { Perceiving low student } \\
\text { interest }\end{array}$ & 159 & 7.27 & 2.01 \\
$\begin{array}{l}\text { Assessing student } \\
\text { learning }\end{array}$ & 52 & 6.94 & 2.15 \\
Total & 16 & 7.93 & 1.29 \\
\hline
\end{tabular}

Table 7 shows that the participants generated 227 statements with three emerging categories. 159 mentions highlighted the lack of abilities to 'generate online learning environments' about which they felt high level of anxiety $(\mathrm{M}=7.27, \mathrm{SD}=2.01)$. According to the qualitative data results (see Table 3), the EFL teachers touched upon issues about authority building, classroom management and empowering learners with interaction-based activities. Particularly, most of their anxiety seems to stem from their inability to develop a sense of teaching that they experienced. Secondly, the analysis revealed 'perceiving low student interest' $(\mathrm{f}=52)$. Teachers noted students' inadequate attempts and efforts to adapt to the online learning setting. They scored this sense with a high degree of anxiety $(\mathrm{M}=6.94, \mathrm{SD}=2.15)$ though this is the lowest degree in comparison to other categories. The last category emerged as 'assessing student learning' with the lowest common concern ( $\mathrm{f}=16)$ but caused the highest source of anxiety $(\mathrm{M}=7.93, \mathrm{SD}=1.29)$ among others. However, though EFL teachers scored it at a greater extent than of generating online learning environments, this category has a mutual relationship with 'generating online learning environments' because once the latter is ensured then assessment may become achievable. In sum, Table 7 provides the extent to which EFL teachers scored their anxiety sources, but which require further tests to be validated across several demographic variables of the participants.

We employed further tests in line with Dörnyei's (2007) argument that statistical significance tests are valuable to processing the quantified qualitative data. The 


\section{Acta Educationis Generalis \\ Volume 12, 2022, Issue 1}

demographic data allowed us to make further statistical analyses. Research question 3 tested scorings of sources of anxiety in terms of different variables with the appropriate parametric and non-parametric tests fitting to the normality test results (See section 2.4 Data analysis).

Table 8

Parametric and non-parametric test results according to different variables and groups

\begin{tabular}{|c|c|c|c|c|c|c|c|c|c|c|c|}
\hline \multirow[b]{2}{*}{ Variable } & \multirow[b]{2}{*}{ Group } & \multicolumn{6}{|c|}{ Digitalisation (Parametric tests) } & \multicolumn{4}{|c|}{$\begin{array}{c}\text { Online Pedagogy } \\
\text { (Non-Parametric tests) }\end{array}$} \\
\hline & & $n$ & Analysis & $M$ & $S D$ & $t$ & $p$ & Analysis & Med & $Z$ & $p$ \\
\hline & Male & 29 & Independent & .69 & .48 & & & Mann- & 48.31 & & \\
\hline \multirow[t]{4}{*}{ Gender } & Female & 67 & Samples & .73 & .45 & & 0.75 & Whitney & 48.58 & -0.044 & 0.965 \\
\hline & Total & 96 & $t$ test & .72 & .46 & 0.315 & & U Test & & & \\
\hline & $<=30$ & 23 & & .71 & .45 & & & & 53.46 & & \\
\hline & $31-40$ & 51 & & .71 & .45 & & & & 43.25 & & \\
\hline \multirow[t]{4}{*}{ Age } & $41-50$ & 19 & Oneway & .77 & .52 & 0.367 & 0.777 & Kruskall & 54.61 & 4.097 & 0.251 \\
\hline & $>50$ & 3 & & .48 & .13 & & & & 61.17 & & \\
\hline & Total & 96 & & .72 & .46 & & & & & & \\
\hline & $<=5$ & 19 & & .78 & .51 & & & & 40.00 & & \\
\hline & $6-10$ & 21 & & .68 & .44 & & & & 55.36 & & \\
\hline \multirow{5}{*}{$\begin{array}{l}\text { Overall } \\
\text { teaching } \\
\text { experience }\end{array}$} & $11-15$ & 27 & Oneway & .72 & .45 & & & Kruskall & 45.20 & & \\
\hline & $16-20$ & 19 & Anova & .68 & .45 & 0.147 & 0.964 & Wallis & 51.89 & 3.949 & 0.413 \\
\hline & $>=21$ & 10 & & .73 & .49 & & & & 52.70 & & \\
\hline & Total & 96 & & .72 & .46 & & & & & & \\
\hline & None & 28 & & .71 & .50 & & & & 41.91 & & \\
\hline \multirow{5}{*}{$\begin{array}{l}\text { Digital } \\
\text { experience }\end{array}$} & Low & 38 & Oneway & .85 & .42 & & & Kruskall & 52.68 & & \\
\hline & High & 30 & Anova & .55 & .42 & 3.783 & $0.026^{*}$ & Wallis & 49.35 & 2.465 & 0.292 \\
\hline & Total & 96 & & .72 & .46 & & & & & & \\
\hline & University & 42 & & .73 & .50 & & & & 52.18 & & \\
\hline & Lg. Center & 3 & & 1.26 & .94 & & & & 34.83 & & \\
\hline \multirow{4}{*}{$\begin{array}{l}\text { Work } \\
\text { Setting }\end{array}$} & High Sch. & 18 & Oneway & .69 & .29 & & & Kruskall & 41.28 & & \\
\hline & Secondary & 18 & Anova & .65 & .40 & 1.215 & 0.31 & Wallis & 46.67 & 2.968 & 0.563 \\
\hline & Primary & 15 & & .67 & .46 & & & & 51.80 & & \\
\hline & Total & 96 & & .72 & .46 & & & & & & \\
\hline
\end{tabular}

Table 8 shows the results of significance tests for comparisons of themes and different variables: participants' gender, age, overall teaching experience, digital teaching experience, and work setting (i.e., K12 level or tertiary level). However, the only statistically significant difference was found between low and high online teaching experience $(\mathrm{p}=0.026)$, meaning low experience might trigger more anxiety in online teaching.

Tabulating the data both from the quantitative and the qualitative research methods, the results indicate that teachers' sources of anxiety fall at the intersection of digitalisation- and online pedagogy-related concerns with high levels of anxiety. This means teachers felt anxious in ERT due to the lack of their affective and cognitive competences to tailor the integration into the new modality, their access to the available information and lastly their safety in terms 


\section{Acta Educationis Generalis \\ Volume 12, 2022, Issue 1}

of the confidentiality of the information. Therefore, these findings imply the need for developing knowledgeable teachers who can develop computer interactions by acting on professional behaviours accordingly. Further, as evidenced particularly with the statistically significant difference tests, participants with low level of experience in online teaching have high level of digitalisation-related anxiety.

\section{Discussion}

In this study, we focused on an underexplored topic in the literature; namely, teaching anxiety in online education (Bollinger, 2017; Russell, 2020). The aim was three-fold: to explore the sources of online teaching anxiety (I), explain the extent to which each source contributed to teachers' anxiety (II) and see whether the level of anxiety differed statistically significantly across demographic variables (III).

The findings of research question 1 showed that after Covid-19, the teachers' sources of anxiety relied on digital and online pedagogical competences in the new modality. The first theme emerged as "Digitalisation-related concerns" covering 'technical challenges', 'lack of infrastructure', 'digital integration' and 'information security, privacy and ethical issues' which are also documented to lead to stress and anxiety among teachers by Çoklar et al. (2016), Picciano et al. (2012), Hassan et al. (2019), and Russell (2020). Specifically, 'lack of infrastructure' might be seen as a challenge in developing countries including Turkey; however, the other categories could be related to the teachers' digital literacy since hesitations occurred on technical skills, digital knowledge, creating digital content and digital security. Also, teachers' digitalisation concerns could be linked to emerging digital citizenships through digital competences as categorized by Janssen et al. (2013): information, communication, contentcreation, safety, and problem-solving. The participants may have had technology knowledge and awareness but their concerns signal their need for digital literacy, which involves mastery of ideas in not only using but also integrating the technology into online pedagogical practices (Tang \& Chaw, 2016, p. 56).

The second theme included concerns related to 'generating online learning environments', 'perceiving low student interest' and 'assessing student learning'. These findings bring unique and specific concerns to be addressed. For example, some participants reported hesitation in how to ensure quality teaching, manage classroom, enhance interaction and build authority, increase motivation and deal with time management. Our participants also highlighted students' reluctance to engage with online learning during ERT (Baloran, 2020), but this is contradicted by Lazarevic and Bentz (2020), who argue using technology reduces stress in online environments compared to the traditional classroom. However, our study shows that the themes we induced appeared to be linked with teachers' inadequate competences to build online pedagogical designs and practices. This shows similarity to the findings of Sahu (2020) in 


\section{Acta Educationis Generalis \\ Volume 12, 2022, Issue 1}

that lack of digital pedagogy could also lead them to feel anxious in assessing students' learning. Additionally, as reported by Wolgast, Hille, Streit and Grützemann (2020), if anxiety is felt emotionally (e.g. in tests), it could afford more opportunities for student teachers to increase perspective-taking tendency. Therefore, some level of anxiety could bring affordances for teachers to develop professional learning in the journey of professional teaching.

The findings of research question 2 showed that the reported sources of anxiety scored by the same participants allowed us to explain how these sources might have contributed to the degree of anxiety about online teaching. The analysis showed neither significant difference nor correlation between the two emerging themes. Recently, in their examination of news media publications after Covid19, Greenhow, Lewin and Staudt Willet (2020) found digital pedagogy as a dominant category among the reported challenges by teachers. However, our study findings made a distinction between the digitalisation and online pedagogy with the dominance of the former to the latter theme. The results showed that lowest scorings were attributed to technical challenges and safety. This shows evidence from the literature that teachers with higher confidence with technology use (particularly internet use) may have tended to score low anxiety because they show traits of higher level of digital literacy (Serafín, Depešová, \& Bánesz, 2019). In addition, another striking finding was teachers' perception of low level of student interest. Though it was the second highest category under digital pedagogy concerns, participants scored it with the lowest degrees of anxiety. This could be related to learners' low level of readiness as also reported by Brinkley-Etzkorn (2020).

The findings of research question 3 indicated that teachers with low levels of experience showed higher anxiety in digitalisation-related concerns than those with higher levels of experience. Our participants had an average of 12 years of teaching experience but only $31 \%$ reported substantial online teaching experience in their professional career. In the pertinent literature, there is evidence that the negative impact of anxiety is higher relatively among novice teachers than experienced teachers (Fernández-Batanero et al., 2021; Hassan et al., 2019). On the other hand, digital competence could be nurtured and cultivated over time as challenges are experienced and adapted (Ghomi \& Redecker, 2018). Since anxiety may be a state or a trait anxiety, the state anxiety fades away after the conditions caused it; therefore, there is a further need to investigate the same participants' anxiety levels in order to see whether it is a trait anxiety being persistent in their psychological status.

\section{Conclusion}

We can conclude that the participants' lack of digital literacy and experience might have caused them to feel anxious about the unknown and inexperienced challenges that can be encountered during ERT. The findings obtained from this study cast evidence on the need for digitally literate and pedagogically 


\section{Acta Educationis Generalis \\ Volume 12, 2022, Issue 1}

transformed teachers. Therefore, we can emphasize the link between anxiety and lack of digital literacy because teachers who self-reported higher digital literacy appeared to score less anxiety about integrating digital resources into pedagogical practices. Yet the findings showed, teachers still attribute their sources of anxiety to the technical and infrastructural challenges, which appeared to trigger anxiety particularly among teachers with relatively less experience in online teaching.

It is significant to note that Turkish Ministry of Education already initiated a nationwide digitalisation project in cooperation with Google to address the multiple challenges, representing the recognition of the need for digitally literate teachers before the outbreak of the Covid-19 (Ministry of National Education, 2019). However, with the present study, we conclude that teachers need to shift their attributions of anxiety to their own digital literacy and to improve the use and integration of digital tools and facilities for multiple pedagogical purposes. The qualitative findings can be representative of the unprecedented experience of Covid-19 in Turkey because the number of participants was strongly satisfactory according to Dörnyei (2007). On the other hand, an online/remote teaching anxiety scale can be developed out of the qualitative excerpts and categories, therefore, larger sampling sizes of quantitative data might measure the level and degree of anxiety better not only in Turkish but also in other contexts in the future.

\section{Suggestions}

In such an ERT transition as witnessed during the Covid-19 pandemic, it is unsurprisingly challenging to create an environment conducive to teacher adaptation to the new course delivery mode. Many studies suggest that training could help reduce anxiety (Fernández-Batanero et al., 2021; Hassan et al., 2019; Russell, 2020) but in this case there was little time or resources to enable these support forms. Therefore, we suggest three main areas of support to facilitate teaching and to address teachers' anxiety on teaching remotely. The first is to officially reduce the teaching load to increase the lesson preparation time and enhance the quality of remote teaching. The second area of support is to offer very short but focused training sessions which give clear hands-on and practical knowledge about how to use the remote teaching platforms to plan courses and engage students, how to make lessons more interactive, and thus, more motivating. The third area is to train teachers on how to offer continuous feedback to further strengthen interaction with learners and support learning.

We propose that we need to develop dynamically active digitalisation programs for teachers and learners who are experiencing a dramatic emotional and cognitive conflict. This is a problem that requires a systematic attention to developing alternatives for overcoming the consequences of this unique global situation, with a view to developing a person in-context perspective. By doing so, there should be opportunities for any emergency situational developed, 


\section{Acta Educationis Generalis \\ Volume 12, 2022, Issue 1}

context-appropriate online pedagogies drawn up on well-established pedagogical principles. This could be created through critical interpretations of theoryinformed local implementations and understandings.

\section{Implications}

There are a number of implications for teachers, teacher educators and educational decision-makers that play a key role in such circumstances. Teachers need to self-identify their anxiety sources and develop local strategies to remain resilient in the face of challenges. They should autonomously develop new ways of interactions with more experienced colleagues to learn from one another and also self-train their skills in online platforms.

Teacher educators and higher education curriculum designers need to reconsider how they could educate teachers for such emergency circumstances, which could reduce the anxiety and its negative effects on teaching. Although faculties offer courses focusing on technology use, teacher educators need to incorporate actual remote teaching experiences by engaging students in online courses, increasing motivation and designing collaborative tasks.

Educational policy makers might need to systematically activate emergency plans to keep teachers in readiness to overcome the challenges of remote teaching. The gradual, but profound and perhaps irreversible nature of educational transformation will also shift the existing mindset of teachers and learners from place-based to online and blended pedagogies supported by hybrid models of learning. These approaches could include how to work with multimodal resources, digital or printed, online or physically present teacher, synchronous or asynchronous interaction, and the consumption or creation of digital media for learning. The teacher education curricula also need to re-situate the learning objectives, outcomes, and outputs in such a way so as to address the online learning experiences and facilities. The learning offered in the classroom will become obsolete unless improvised with alternative models involving a multimodal digital approach to teaching.

\section{References}

Aslrasouli, M., \& Vahid, M. S. P. (2014). An investigation of teaching anxiety among novice and experienced Iranian EFL teachers across gender. Procedia-Social and Behavioral Sciences, 98(5), 304-313. https://doi.org/10.1016/j.sbspro.2014.03.421

Baloran, E. T. (2020). Knowledge, attitudes, anxiety, and coping strategies of students during COVID-19 pandemic. Journal of Loss and Trauma, 25(8), 635-642. https://doi.org/10.1080/15325024.2020.1769300

Basilaia, G., \& Kvavadze, D. (2020). Transition to online education in schools during a SARSCOV-2 coronavirus (COVID-19) pandemic in Georgia. Pedagogical Research, 5(4), 1-9. https://doi.org/10.29333/pr/7937

Bollinger, A. (2017). Foreign language anxiety in traditional and distance learning foreign language classrooms (Doctoral dissertation). Lynchburg, VA: Liberty University. 


\section{Acta Educationis Generalis \\ Volume 12, 2022, Issue 1}

Brinkley-Etzkorn, K. E. (2020). The effects of training on instructor beliefs about and attitudes toward online teaching. American Journal of Distance Education, 34(1), 19-35. https://doi.org/10.1080/08923647.2020.1692553

Crawford, J., Butler-Henderson, K., Rudolph, J., \& Glowatz, M. (2020). Covid-19: 20 countries' higher education intra-period digital pedagogy responses. Journal of Applied Teaching and Learning (JALT), 3(1). https://doi.org/10.37074/jalt.2020.3.1.7

Creswell, J. W. (2007). Qualitative inquiry and research method: Choosing among five approaches (2nd edition). Sage.

Creswell, J. W. (2011). Educational research: Planning, conducting, and evaluating quantitative and qualitative research. Pearson.

Creswell, J. W., \& Poth, C. N. (2016). Qualitative inquiry and research design: Choosing among five approaches. Sage.

Çoklar, A. N., Efilti, E., Şahin, Y. L., \& Akçay, A. (2016). Investigation of techno-stress levels of teachers who were included in technology integration processes. Turkish Online Journal of Educational Technology, Special Issue for INTE, 1331-1339.

Dikilitaş, K. (2015). Teacher research for instructors. In S. Borg (Ed.), Professional Development for English Language Teachers: Perspectives from Higher Education in Turkey (pp. 27-33). Ankara: British Council.

Dörnyei, Z. (2007). Research methods in applied linguistics. Quantitative, qualitative and mixed methodologies. Oxford University Press.

Driscoll, A., Jicha, K., Hunt, A. N., Tichavsky, L., \& Thompson, G. (2012). Can online courses deliver in-class results? A comparison of student performance and satisfaction in an online versus a face-to-face introductory sociology course. Teaching Sociology, 40(4), 312-331. https://doi.org/10.1177/0092055X12446624

Ellis, R. A., \& Calvo, R. A. (2007). Minimum indicators to assure quality of lms-supported blended learning. Educational Technology \& Society, 10(2), 60-70. https://www.jstor.org/stable/jeductechsoci.10.2.60

Fernández-Batanero, J. M., Román-Graván, P., Reyes-Rebollo, M. M., \& Montenegro-Rueda, M. (2021). Impact of educational technology on teacher stress and anxiety: A literature review. International Journal of Environmental Research and Public Health, 18(2), 548. https://doi.org/10.3390/ijerph18020548

Ghomi, M., \& Redecker, C. (2018). Digital competence of educators (digcompedu): Development and evaluation of a self-assessment instrument for teachers' digital competence. Joint Research Center.

Greenhow, C., Lewin, C., \& Staudt Willet, K. B. (2020). The educational response to Covid-19 across two countries: A critical examination of initial digital pedagogy adoption. Technology, Pedagogy and Education, 1-19. https://doi.org/10.1080/1475939X.2020. 1866654

Guba, E. G., \& Lincoln, Y. S. (1989). Fourth generation evaluation. Sage.

Guba, E. G., \& Lincoln, Y. S. (2005). Paradigmatic controversies, contradictions and emerging confluences. In N. K. Denzin, \& Y. S. Lincoln (Eds.), The Sage Handbook of Qualitative Research (3rd ed., pp.1-32). Sage.

Hassan, N., Yaakob, S. A., Halif, M. M., Aziz, R. A., Majid, A. A., \& Sumardi, N. A. (2019). The effects of technostress creators and organizational commitment among school teachers. Asian Journal of University Education, 15, 92-102. http://ir.uitm.edu.my/id/eprint/29744

Hubalovsky, S., Hubalovska, M., \& Musilek, M. (2019). Assessment of the influence of adaptive E-learning on learning effectiveness of primary school pupils. Computers in Human Behavior, 92, 691-705. https://doi.org/10.1016/j.chb.2018.05.033

İpek, H. (2016). A qualitative study on foreign language teaching anxiety. Journal of Qualitative Research in Education, 4(3), 92-105. https://doi.org/10.14689/issn.2148-2624.1.4c3s5m 


\section{Acta Educationis Generalis \\ Volume 12, 2022, Issue 1}

Janssen, J., Stoyanov, S., Ferrari, A., Punie, Y., Pannekeet, K., \& Sloep, P. (2013). Experts' views on digital competence: Commonalities and differences. Computers \& Education, 68(1), 473481. https://doi.org/10.1016/j.compedu.2013.06.008

Kohnke, L., \& Moorhouse, B. L. (2020). Facilitating synchronous online language learning through Zoom. RELC Journal. https://doi.org/10.1177/0033688220937235

Lall, S., \& Singh, N. (2020). Covid-19: Unmasking the new face of education. International Journal of Research in Pharmaceutical Sciences, 11(SPL1), 48-53. https://doi.org/10.26452/ijrps.v11iSPL1.2122

Lazarevic, B., \& Bentz, D. (2020). Student perception of stress in online and face-to-face learning: the exploration of stress determinants. American Journal of Distance Education, 1-14. https://doi.org/10.1080/08923647.2020.1748491

Liguori, E. W., \& Winkler, C. (2020). From offline to online: Challenges and opportunities for entrepreneurship education following the COVID-19 pandemic. Entrepreneurship Education and Pedagogy. https://doi.org/10.1177/2515127420916738

MacIntyre, P. D., Gregersen, T., \& Mercer, S. (2020). Language teachers' coping strategies during the Covid-19 conversion to online teaching: Correlations with stress, wellbeing and negative emotions. System, 94, 102352. https://doi.org/10.1016/j.system.2020.102352

McMahon, S. A, \& Winch, P. J. (2018). Systematic debriefing after qualitative encounters: An essential analysis step in applied qualitative research. BMJ Glob Health, 3(5), 1-6. http://dx.doi.org/10.1136/bmjgh-2018-000837

Miles, M. B., \& Huberman, A. M. (1994). Qualitative data analysis: An expanded sourcebook (2nd edition). Sage.

Ministry of National Education (2019). News from Ministry of National Education. Retrieved from https://www.meb.gov.tr/1-milyon-ogretmen-icin-google-ile-birlikte-dijital-donusumprogrami/haber/19854/tr

Moorhouse, B. L., \& Beaumont, A. M. (2020). Utilizing video conferencing software to teach young language learners in Hong Kong during the COVID-19 class suspensions. TESOL Journal, 11(3), e00545. https://doi.org/10.1002/tesj.545

Özer, M. (2020). Educational policy actions by the ministry of national education in the times of Covid-19 pandemic in Turkey. Kastamonu Education Journal, 28(3), 1124-1129. https://doi.org/10.24106/kefdergi.722280

Paechter, M., Maier, B., \& Macher, D. (2010). Students' expectations of, and experiences in elearning: Their relation to learning achievements and course satisfaction. Computers \& Education, 54(1), 222-229. https://doi.org/10.1016/j.compedu.2009.08.005

Picciano, A. G., Seaman, J., Shea, P., \& Swan, K. (2012). Examining the extent and nature of online learning in American K-12 education: The research initiatives of the Alfred P. Sloan Foundation. The Internet and Higher Education, 15, 127-135. https://doi.org/10.1016/j.iheduc.2011.07.004

Rodrigues, H., Almeida, F., Figueiredo, V., \& Lopes, S. L. (2019). Tracking e-learning through published papers: A systematic review. Computers \& Education, 136, 87-98. https://doi.org/10.1016/j.compedu.2019.03.007

Ross, A. F., \& DiSalvo, M. L. (2020). Negotiating displacement, regaining community: The Harvard Language Center's response to the COVID-19 crisis. Foreign Language Annals, 53(2), 371-379. https://doi.org/10.1111/flan.12463

Russell, V. (2020). Language anxiety and the online learner. Foreign Language Annals, 53(2), 338-352. https://doi.org/10.1111/flan.12461

Sahu, P. (2020). Closure of universities due to coronavirus disease 2019 (COVID-19): Impact on education and mental health of students and academic staff. Cureus, 12(4). https://dx.doi.org/10.7759\%2Fcureus. 7541

Saldaña, J. (2021). The coding manual for qualitative researchers (4th edition). Sage.

Serafín, Č., Depešová, J., \& Bánesz, G. (2019). Understanding digital competences of teachers in Czech Republic. European Journal of Science and Theology, 15(1), 125-132. 


\section{Acta Educationis Generalis \\ Volume 12, 2022, Issue 1}

UNESCO (2020). COVID-19 Impact on Education. Retrieved from https://en.unesco.org/covid19/educationresponse

Wolgast, A., Hille, M., Streit, P., \& Grützemann, W. (2020). Does test-anxiety experience impair student teachers' later tendency to perspective-taking? Acta Educationis Generalis, 10(1), 124. https://doi.org/10.2478/atd-2020-0001

Tabachnick, B. G., \& Fidell, L. S. (2007). Using multivariate statistics (5th edition). Pearson.

Taguchi, N. (2020). Digitally mediated remote learning of pragmatics. Foreign Language Annals, 53(2), 353-358. https://doi.org/10.1111/flan.12455

Tang, C. M., \& Chaw, L. Y. (2016). Digital literacy: A prerequisite for effective learning in a blended learning environment? The Electronic Journal of e-Learning, 14(1), 54-65.

Tekerek, M., \& Tekerek, A. (2013). A research on students' information security awareness. Turkish Journal of Education, 2(3), 61-70. https://doi.org/10.19128/turje.181065

Yang, J. C., Lin, M. Y. D., \& Chen, S. Y. (2018). Effects of anxiety levels on learning performance and gaming performance in digital game-based learning. Journal of Computer Assisted Learning, 34(3), 324-334. https://doi.org/10.1111/jcal.12245

Young, D. J. (1991). Creating a low-anxiety classroom environment: What does language anxiety research suggest? The Modern Language Journal, 75(4), 426-439. https://doi.org/10.2307/329492

Young, S. S. C. (2003). Integrating ICT into second language education in a vocational high school. Journal of Computer Assisted Learning, 19(4), 447-461. https://doi.org/10.1046/j.0266-4909.2003.00049.x 